\title{
A Comparative Study of Product, Process, and Post-process Approaches in Iranian EFL Students' Writing Skill
}

\author{
Hossein Hashemnezhad \\ Department of English Language Teaching, Khoy Branch, Islamic Azad University, Khoy, Iran \\ Email: h_hashemnezhad2000@yahoo.com \\ Nasrin Hashemnezhad \\ Department of English Language Teaching, Khoy Branch, Islamic Azad University, Khoy, Iran \\ Email: nasrinhashemnezhad@yahoo.com
}

\begin{abstract}
The purpose of the present study is to find the possible difference among Iranian EFL learner's writing ability in terms of three writing approaches of product, process, and post-process. The participants of the study included 60 EFL sophomores who were non-randomly selected out of 100 students at Azad University. The students had similar educational backgrounds in that they had been exposed to Writing Course I as prerequisite to Writing Course II. The participants' ages ranged from 19-26. They were all TEFL bilinguals (Azari and Persian) who were taking writing course (II) at Islamic Azad University. The researchers divided research sample into three groups of 20 . All three groups were exposed to three different approaches. The first group was exposed to the product approach, the second group to the process approach and the third group exposed to the post-process approach respectively. In order to evaluate the effectiveness of three different writing approaches, the researcher gave two identical post-tests (cause-effect and procedural) to all three groups. The findings of the study revealed that post process approach did not show any significant priorities over process approach, but they both indicated remarkable priority over product approach. Finally implications were drawn for EFL teachers, students, and syllabus designers.
\end{abstract}

Index Terms-EFL writing, post-process writing, process writing, product writing

\section{INTRODUCTION}

Writing is an essential learning tool because it helps students to better understand ideas and concepts. It is obvious that writing occupies a noticeable place in research and pedagogy due to the ever-growing number of students enrolled in higher-education institutions in English speaking countries and also to the recognition of changes in global realities. In fact, the field of second language writing is an area affecting the lives of many people at institutions around the world where they must submit high quality written work in a language they did not learn as native speakers. There are several reasons that the ability to speak and write a second language is a crucial important tool or a significant skill for people of all works of life in today's global community.

Weigle (2002) states that teaching and measuring of writing is a specific component of English language teaching. A study done by Sommers (2002, cited in Foo, 2007) and a team of researchers at Harvard University traced the writing experiences of more than four hundred undergraduates undergoing different courses over a period of four years, showed the majority of the students believe that writing helps them understand and apply the ideas of a course. Although students may read to gather information, it is finally through writing that their ideas are made clear and their thoughts made perceptible. Writing is one of the important tools by which students actively change the passive knowledge and information in their minds into their own language. Chandrasegaran (1991, cited in Foo, 2007) points out the importance of being able to write coherent, well organized expository essays at university because academic assessment is almost completely based on these written products in coursework and examinations throughout the period of the courses.

Now, a range of approaches can be pulled to teaching writing by EFL teachers. Over the last twenty years, process and product approaches have dominated much of the teaching of writing that take place in the EFL classroom. In the last ten years, post process approaches have gained several advocates (e.g., see Swales 1990; Tribble 1996).

One of the most explicit descriptions of product approaches is provided by Pincas (1982, cited in Badger \& White, 2000). She views writing as being mainly about linguistic knowledge, with attention paid on the proper use of vocabulary, syntax, and cohesive devices.

Process-oriented pedagogy is encouraged through practices such as requiring multiple drafts, peer review, and portfolio-based class assessment. Tribble (1996) suggested that process approaches stress "Writing activities which move learners from the generation of ideas and the collection of data through to the 'publication' of a finished text" (p. 
37).Hedge (1988, cited in Badger \& White, 2000) identified four elements of the context that pre-writing activities should focus on: the audience, the generation of ideas, the organization of the text, and its purpose.

Sinor and Huston (2004, cited in He, 2005) stated that post-process does not abandon the writing steps; in fact, working through the writing steps is a crucial component while instruction is centered on the social, political, and contextual forces that surround writing. Some scholars as social constructionists see writing as "a social artifact with political as well as social implications" (Santos, 1992, cited in He, 2005, p.31).

With the development of second language literacy research, writing in ESL/EFL settings has gained much attention. Scholars and researchers are trying to find ways of teaching writing to a growing number of ESL and EFL students. What kind of teaching pedagogy should teachers apply to L2 writing classes? How can teachers teach writing to ESL/ EFL students? Should teachers focus on the writing product, on the writing process, or on the writing post process? The answer to these questions is the most challenging one in the field of L2 teaching writing.

\section{REVIEW OF THE RELATED LITERATURE}

Though applied linguists have come to recognize the importance of writing in its own right and complexity, in general, writing remains one of the least well-understood subjects in applied linguistics. One reason is the ambiguity of the term writing which has been used in referring to orthography, written discourse, and the act of writing or even literature and the prevalence of the definition of writing as mere orthography in linguistic sciences during the last two centuries. Although the body of research in applied linguistics focusing on writing and writing instruction has grown exponentially over the last few decades, writing continues to be marginalized in mainstream second language acquisition research (Harklau, 2000; Leki, 2000, both cited in Schmitt, 2002) and many well-known introductory linguistics textbooks still perpetuate the view of writing as an orthographic representation of speech.

Harmer (2004) indicated that writing has always formed part of the syllabus in the teaching of English language. However, it can be used for a variety of purpose, ranging from being merely a 'backup' for grammar teaching to a major syllabus strand in its own right, where mastering the ability to write effectively is considered as a crucial important tool for learners. One of the most important achievements of education is to help students to write well. Beyond writing's role in work success (Dempsy, Pytlikzillig, \& Bruning, 2009), writing is a key factor in the development of problemsolving and critical-thinking skills.

The EFL writing class may be regarded as a workshop for students to learn to create academic essays through mastering techniques for getting started and generating ideas, drafting papers which they will anticipate revising, and learning to use feedback from the teacher and other students in the class to improve the writing assignment at hand. The goal of every course should be individual student progress in writing proficiency, and the goal of the total curriculum should be that student writers learn to become informed and independent readers of their own texts with the ability to create, revise, and reshape papers to meet the needs of whatever writing tasks they are assigned (Kroll, 2001, cited in Ferris \& Hedgcock 2005).

\section{A. Feedback on EFL Writing}

As Nunan (2001) pointed, feedback is the provision of information to speakers about the message they have conveyed. Neutral feedback informs the speaker that the message has been received. It may be verbal or nonverbal.

As Ferris \&Hedgcock (2005) stated teacher response to student writing is important at all levels and in all instructional contexts. However, responding effectively to student writing is a skill that can elude even experienced teachers.

\section{B. Product Writing}

Pincas (1982, cited in Badger \& White, 2000) realizes learning as assisted imitation, and adopts many techniques (e.g. substitution tables), where learners respond to a stimulus provided by the teacher. However, her comment that, at the stage of free writing, students should feel as if they are creating something of their own suggests a view of learners as being ready to show rather more initiative. In short, product-based approaches see writing as mainly concerned with knowledge about the structure of language, and writing development as mostly the result of the imitation of input, in the form of texts provided by the teacher.

\section{Process Writing}

The 1960s, 1970s, and 1980s witnessed a highly influential trend in L1 composition pedagogy and research. Raimes (1985) and Zamel (1982) were among the strongest voices calling for process writing.

Zamel (1982) claims that the composing processes of L1 writers can be suitable to ESL writers, but teacher-guided revision is the main focus of instruction in ESL classes. Process approaches, as they now are generally labeled, emphasized the individual writer as a creator of original ideas. It was believed that written discourse encoded these ideas, helping as a vehicle for exploring one, conveying one's thoughts, and claiming one's individual voice, or authorial persona, as a writer. Process-oriented writing pedagogies focused particular attention on procedures for solving problems, discovering ideas, expressing them in writing, and revising emergent texts - typically, in isolation from any cultural, educational, or sociopolitical contexts in which writing might take place. 
Zamel (1982) also points out that writing is a process of discovering and making meaning and that the writing process is recursive, nonlinear, and convoluted.

\section{Post-process Writing}

The term post-process arose in composition studies during the early 1990s and quickly became one of the significant keywords, shaping the development of an intellectual current in the field. Atkinson locates the origin of the term in Trimbur's (1994, cited in Matsuda, 2003) review article in College Composition and Communication, although, as he notes, the critique of the process movement had begun much earlier.

Atkinson ( 2003) defines post process as including everything that follows, generally speaking, the period of L2 writing instruction and research that focused primarily on writing as a cognitive or internal, multi-staged process, and in which by far the major dynamic of learning was through doing, with the teacher taking a background role.

\section{STATEMENT OF THE PROBLEM}

Although the teaching of writing has undergone major changes in the last two decades, Iranian EFL students still seem to be receiving inadequate or outmoded writing instruction. In Iranian writing classes, little instruction in writing is offered at school levels and that writing is seen as an ancillary skill supporting the learning of grammar and, rarely as a means of expressing comprehension.

One question relevant to this study can be finding the strengths and weaknesses of product, process, and post-process approaches to writing in terms of their view of writing and how they see the development of writing in Iranian classes and which approach is better for Iranian academic writing classes. In Iran, no researches carried out around this problem. Based on some foreign researches, there are some L2 writing lacks in covering this problem. Clearly, there needs to be an approach that bridges the essential differences between product, process and post process approaches.

\section{RESEARCH QUESTION}

The overall aim of this study is formed into more specific objective, which is expressed in the form of the research question and hypothesis below:

- Is there any significant difference among Iranian EFL learners' writing ability in terms of product, process, and post process writing approaches?

\section{RESEARCH HYPOTHESIS}

Accordingly, the following hypothesis is formulated from the above research question:

- There are significant differences among Iranians' writing ability in terms of product, process, and post-process writing approaches.

\section{METHOdOLOGY}

\section{A. Participants}

The participants of the study included 60 EFL sophomores who were non- randomly selected out of 100 students at Islamic Azad University. The students had similar educational backgrounds in that they had been exposed to writing course I as prerequisite to writing course II. The participants' ages ranged from 19-26. They were all TEFL bilinguals (Azari and Persian) who were taking writing course II at Islamic Azad University, Khoy branch. The researcher divided research sample into three groups of 20. All three groups were exposed to three different approaches. The first group was exposed to the product approach, the second group to the process approach and the third group to post process approach.

\section{B. Instrumentation}

This study proceeded in applying three instruments:

First, Textbook: The research textbook is entitle Paragraph Development by Arnodet and Barret (1981).

Second, Final Exam: In order to evaluate the effectiveness of three different writing approaches, the researcher gave two identical post-tests (cause-effect and procedural) to all three groups. The post test was two identical writing topics for all participants in all three groups.

Third, Analytic Rating Scale: This questionnaire included two main sections. Section one was based on Ashweel (2000) and included five different sections of ability to communicate, logical organization, purpose of each paragraph, smooth ideas, and finally relevant supportive ideas. Each of the major sections was divided into six subsections and the raters chose a point along a scale (4-point Likert scale) that corresponded to their understanding of examinees' knowledge and improvement in writing ability.

Section two was based on Lee (2006); Song and August (2002). This section included three different sections of grammar, vocabulary, and mechanics. Each of the major sections was divided into four subsections and the raters chose a point along a scale (4-point Likert scale). 


\section{Procedures}

Sixty EFL students were non- randomly selected out of 100 EFL sophomores studying at Azad University. Then the sample divided into three major groups of product group, process group, and post process group. Each group exposed to experimental treatment for sixteen sessions in an academic term. The teacher and the textbook were the same for all 3 groups. The researcher evaluated the students' progress through final exams.

The first group, product approach was a traditional approach, in which students were encouraged to mimic a model text, which was presented and analyzed at an early stage. In this approach, there were pre-writing and writing only. There were four stages in product writing. Familiarization aimed to make learners aware of certain features of a particular text. In Controlled writing, students produced some simple sentences about the topic from a substitution table. According to Ferris and Hedgcock (2005), the teacher in controlled writing exercises also provided a single paragraph to students and asked them to do some changes, for example change the paragraph into past tense. In Guided writing, students had a sample paragraph or series of drawings. Then they had to write another paragraph for themselves. The students might answer some questions to get ideas for the paragraph. Finally, in free writing stage students were ready to write a paragraph.

The second group, process writing, was seen as predominantly to do with linguistic skills, such as planning and drafting, and there was much less emphasis on linguistic knowledge, such as knowledge about grammar and text structure. There were five stages in producing a piece of writing. In prewriting, in order to help students to write and gather information about the topic, the researchers used making a list technique. The teacher, with the help of the students, started to write some sentences on the board. In Composing/drafting stage, the students selected and structured the result of the brainstorming session to provide a plan to write. This guided the first draft of writing. After finishing their first draft, students revised them individually and in collaboration with peers. Then they had their second and third drafts. Editing stage required the students to edit their revising drafts to find their errors in grammar, punctuation, usage, and spelling. Finally, the researcher read the students' papers and provided feedback to them. Feedback in this stage included written indirect coded feedback.

The third group received post-process or genre approach. One of the central insights of genre analysis is that writing is embedded in a social situation, so that a piece of writing is meant to achieve a particular purpose which comes out of a particular situation. There were five stages in this group and the researchers followed the principles and stages of postprocess writing approach. In stage one, collaborative learning, the teacher divided the participants into groups of four. All participants in each group were formed on the basis of some commonality or homogeneity (Jacobs, 2006). Next, the teacher used Numbered Heads Together (Kagan, 1994, cited in Wilhelm, 2006). In stage two, genre awareness, postprocess writing and a model of a particular genre was introduced and analyzed by the researcher .In Stage three, Real Purpose/ Needs analysis, in order to identify students' needs and their interests, a questioner should be distributed in stage three, but it was ignored in the present study since it was limited only to cause/effect and procedural genre. In stage four, the teacher applied socio-affective strategies in the classroom. She encouraged the students to use the following strategies: 1. Questions for clarification 2. Cooperation 3. Self-talk 4. Self-reinforcement. Finally, in stage five, the teacher held collaborative teacher to student conferencing with the individual students about completed work or about work in progress.

\section{RESULTS}

As stated earlier, 60 EFL students were non-randomly selected out of 100 EFL students. The researchers controlled and matched all the 60 students based on three controlled variables of sex, age, and students' previous scores in last writing course. The students' assignments into three groups were nearly the same from viewpoint of sex and age but their previous sores in last writing term were nearly different. That is why the researchers labeled students' previous scores in last writing course as Previous Groups (Writing I) and the groups under study as Experimental Groups. The researchers aimed to prove that post experimental differences are attributed to the conditions of the experiment, rather than to preexisting subject differences, such as sex and previous writing score in previous term. To do so, first, the researchers measured the significant differences among three groups in terms of their previous scores in previous writing term.

Descriptive Statistics for both Previous and Experimental Scores in Three Groups

TABLE I

DESCRIPTIVE STATISTICS

\begin{tabular}{|l|l|l|l|l|l|}
\hline & $\mathrm{N}$ & Mean & Std. Deviation & Minimum \\
\hline Experimental -Product & 20 & 14.3000 & 2.69698 & 8.00 & Maximum \\
Experimental -Process & 20 & 16.1500 & 2.18307 & 19.00 \\
Experimental -Post-process & 20 & 16.5500 & 2.11449 & 12.00 & 20.00 \\
Previous-Product & 20 & 14.1500 & 1.26803 & 13.00 & 20.00 \\
Previous -Process & 20 & 15.0500 & 1.70062 & 13.00 & 17.00 \\
Previous -Post-process & 20 & 15.1000 & 1.48324 & 13.00 & 18.00 \\
\hline
\end{tabular}


Table I shows that the maximum and minimum mean belong to experimental post process (16.55) and previous product (14.15) respectively. In order to examine if the scores in both previous and experimental three groups were normally distributed, One Sample Kolmogorov-Smirnov Test (K.S) was calculated.

The Result of One-Sample Kolmogorov-Smirnov Test for all Three Groups in both Previous and Experimental Test Administrations

TABLE II

ONE-SAMPLE KOLMOGOROV-SMIRNOV TEST

\begin{tabular}{|c|c|c|c|c|c|c|c|}
\hline & & $\begin{array}{l}\text { Experimental } \\
\text { PRODUCT }\end{array}$ & $\begin{array}{l}\text { Experimental - } \\
\text { PROCESS }\end{array}$ & $\begin{array}{l}\text { Experimental } \\
\text { POST- } \\
\text { PROCESS }\end{array}$ & $\begin{array}{l}\text { Previous- } \\
\text { PRODUCT }\end{array}$ & $\begin{array}{l}\text { Previous- } \\
\text { PROCESS }\end{array}$ & $\begin{array}{l}\text { Previous- } \\
\text { POST } \\
\text { PROCESS } \\
\end{array}$ \\
\hline $\mathrm{N}$ & & 20 & 20 & 20 & 20 & 20 & 20 \\
\hline Normal & Mean & 14.3000 & 16.1500 & 16.5500 & 14.1500 & 15.0500 & 15.1000 \\
\hline Parameters ${ }^{\mathrm{a}, \mathrm{b}}$ & Std. Deviation & 2069698 & 2.18307 & 2.11449 & 1.26803 & 1.70062 & 1.48324 \\
\hline Most Extreme & Absolute & .152 & .149 & .166 & .297 & .162 & .177 \\
\hline Differences & Positive & .098 & .149 & .166 & .297 & .162 & .177 \\
\hline Negative & & -.152 & -.104 & -.134 & -.182 & -.124 & -.123 \\
\hline Kolmogorov-Sr & irnov Z & .682 & .664 & .741 & 1.329 & .723 & .791 \\
\hline Asymp. Sig. (2- & ailed) & .742 & .770 & .642 & .059 & .672 & .559 \\
\hline
\end{tabular}

Table II illustrates that there are not any significant differences among scores in each group.

$\mathrm{P}$ value for all groups are higher than 0.05 (sig. for all groups are respectively $=.742, .770, .642, .059, .672, .550>$ 0.05). We conclude that the scores in each three groups, both previous and experimental groups, were normally distributed and we are allowed to use One Way Parametric ANOVA Test for both test administration.

Statistics for Three Groups in Previous Test administration (the writing scores of previous term)

The Result of Descriptive Statistics for One Way ANOVA for all Three Groups in Previous test Administration

TABLE III

DESCRIPTIVES: PERVIOUS TEST ADMINISTRATION

\begin{tabular}{|c|c|c|c|c|c|c|c|c|}
\hline & \multirow[b]{2}{*}{$\mathrm{N}$} & \multirow[b]{2}{*}{ Mean } & \multirow[b]{2}{*}{ Std. Deviation } & \multirow[b]{2}{*}{ Std. Error } & \multicolumn{2}{|c|}{$\begin{array}{l}95 \% \text { Confidence Interval for } \\
\text { Mean }\end{array}$} & \multirow[b]{2}{*}{ Minimum } & \multirow[b]{2}{*}{ Maximum } \\
\hline & & & & & Lower Bound & Upper Bound & & \\
\hline $\begin{array}{l}\text { PRODUCT } \\
\text { PROCESS } \\
\text { POST-PROCESS } \\
\text { Total } \\
\end{array}$ & $\begin{array}{l}20 \\
20 \\
20 \\
60\end{array}$ & $\begin{array}{l}14.1500 \\
15.0500 \\
15.1000 \\
14.7667\end{array}$ & $\begin{array}{l}1.26803 \\
1.70062 \\
1.48324 \\
1.53343 \\
\end{array}$ & \begin{tabular}{|l}
.28354 \\
.38027 \\
.33166 \\
.19797 \\
\end{tabular} & $\begin{array}{l}13.5565 \\
14.2541 \\
14.4058 \\
14.3705\end{array}$ & $\begin{array}{l}14.7435 \\
15.8459 \\
15.7942 \\
15.1628\end{array}$ & $\begin{array}{l}13.00 \\
13.00 \\
13.00 \\
13.00\end{array}$ & $\begin{array}{l}17.00 \\
18.00 \\
18.00 \\
18.00\end{array}$ \\
\hline
\end{tabular}

Table III shows that the maximum and minimum mean belong to post process writing (15.10) and product writing (14.15) respectively.

Test of Homogeneity of Variance

TABLE IV

PERVIOUS TEST ADMINISTRATION

\begin{tabular}{|l|l|l|l|}
\hline Levene Statistic & df1 & df2 & Sig. \\
\hline 1.166 & 2 & 57 & .319 \\
\hline
\end{tabular}

Levene's test for homogeneity of variance with a significance value of $(.319>0.05)$ indicates that variances for all three groups in previous test administrations do not differ significantly. The result allows the researcher to use the slightly more powerful test, called One Way ANOVA.

The Result of One Way ANOVA Test for Three Groups in Previous Test Administration

TABLE V

ANOVA: PERVIOUS TEST ADMINISTRATION

\begin{tabular}{|l|l|l|l|l|l|}
\hline \multicolumn{5}{c|}{ ANOVA: PER VIOUS TEST ADMINISTRATION } \\
\hline Sum of Squares & df & Mean Square & F & Sig. \\
Within Groups & 11.433 & 2 & 5.717 & 2.560 & .086 \\
Total & 127.300 & 57 & 2.233 & & \\
\hline
\end{tabular}

One Way ANOVA test with a significance value of $(.086>0.05)$ indicates that scores for all three groups in previous test administrations do not differ significantly and there are not any significant differences among the scores of three groups in previous test administration.

As a Post Hoc to One Way ANOVA, the researchers used Scheffe test to measure the significant differences between two groups (multiple comparisons).

The Result of Post Hoc Tests: Scheffe (Multiple Comparisons) for Groups in Previous Test Administration 
TABLE VI

PREVIOUS TEST ADMINISTRATION

\begin{tabular}{|c|c|c|c|c|c|c|}
\hline \multirow[b]{2}{*}{ (I) GROUP } & \multirow[b]{2}{*}{ (J) GROUP } & \multirow[b]{2}{*}{ Mean Difference (I-J) } & \multirow[b]{2}{*}{ Std. Error } & \multirow[b]{2}{*}{ Sig. } & \multicolumn{2}{|c|}{$95 \%$ Confidence Interval } \\
\hline & & & & & Lower Bound & Upper Bound \\
\hline \multirow[t]{2}{*}{ PRODUCT } & PROCESS & -.90000 & .47258 & .172 & -2.0878 & .2878 \\
\hline & POST-PROCESS & -.95000 & .47258 & .142 & -2.1378 & .2378 \\
\hline \multirow[t]{2}{*}{ PROCESS } & PRODUCT & .90000 & .47258 & .172 & -.2878 & 2.0878 \\
\hline & POST-PROCESS & -.05000 & .47258 & .994 & -1.2378 & 1.1378 \\
\hline \multirow[t]{2}{*}{ POST-PROCESS } & PRODUCT & .95000 & .47258 & .142 & -.2378 & 2.1378 \\
\hline & PROCESS & .05000 & .47258 & .994 & -1.1378 & 1.2378 \\
\hline
\end{tabular}

Scheffe test with significance values of $(.172, .142, .172, .994, .142, .994>0.05)$ indicates that there are not any significant differences between the scores of three groups in previous test administration.

Statistics for Three Groups in Experimental Test administration (the writing scores for experimental groups)

TABLE VII

THE RESUlt OF DESCRIPTIVE STATISTICS FOR ONE WAY ANOVA FOR ALL THREE GROUPS IN EXPERIMENTAL GROUPS

\begin{tabular}{|c|c|c|c|c|c|c|c|c|}
\hline & \multirow[b]{2}{*}{$\mathrm{N}$} & \multirow[b]{2}{*}{ Mean } & \multirow[b]{2}{*}{ Std. Deviation } & \multirow[b]{2}{*}{ Std. Error } & \multicolumn{2}{|c|}{$\begin{array}{l}95 \% \text { Confidence Interval for } \\
\text { Mean }\end{array}$} & \multirow[b]{2}{*}{ Minimum } & \multirow[b]{2}{*}{ Maximum } \\
\hline & & & & & Lower Bound & Upper Bound & & \\
\hline PRODUCT & 20 & 14.3000 & 2.69698 & .60306 & 13.0378 & 15.5622 & 8.00 & 19.00 \\
\hline PROCESS & 20 & 16.1500 & 2.18307 & .48815 & 15.1283 & 17.1717 & 12.00 & 20.00 \\
\hline POST-PROCESS & 20 & 16.5500 & 2.11449 & .47281 & 15.5604 & 17.5396 & 12.00 & 20.00 \\
\hline Total & 60 & 15.6667 & 2.50874 & 32388 & 15.0186 & 16.3147 & 8.00 & 20.00 \\
\hline
\end{tabular}

Table VII shows that the maximum and minimum mean belong to post process (16.55) and product (14.30) respectively.

Test of Homogeneity of Variances

TABLE VIII

FOLLOWING TEST ADMINISTRATION( EXPERIMENTAL GROUPS
\begin{tabular}{|l|l|l|l|}
\hline Levene Statistic & df1 & df 2 & Sig. \\
\hline .606 & 2 & 57 & .549 \\
\hline
\end{tabular}

Levene's test for homogeneity of variance with a significance value of $(.549>0.05)$ indicates that variances for all three groups in experimental groups do not differ significantly. The result allows the researcher to use the slightly more powerful test, called One Way ANOVA.

The Result of One Way ANOVA Test for Three Groups in Following Test Administration (Experimental Groups)

TABLE IX

ANOVA: FOLLOWING TEST ADMINISTRATION (EXPERIMENTAL GROUPS)

\begin{tabular}{|l|l|l|l|l|l|}
\hline & Sum of Squares & df & Mean Square & F & Sig. \\
\hline Between Groups & 57.633 & 2 & 28.817 & 5.236 \\
Within Groups & 313.700 & 57 & 5.504 & \\
Total & 371.333 & 59 & & \\
\end{tabular}

One Way ANOVA test with a significance value of $(.086>0.008)$ indicates that scores for all three groups in experimental groups do differ significantly and there are significant differences among the scores of three groups in following test administration.

As a Post Hoc to One Way ANOVA, the researcher used Scheffe test to measure the significant differences between two groups (multiple comparisons).

TABLE X

The Result of Post Hoc Tests: SCHEFFe (MultiPle COMPARISONS) FOR GROUPS IN FOLLOWING TEST ADMINISTRATION (EXPERIMENTAL GROUPS)

\begin{tabular}{|c|c|c|c|c|c|c|}
\hline \multirow[b]{2}{*}{ (I) GROUP } & \multirow[b]{2}{*}{ (J) GROUP } & \multirow[b]{2}{*}{ Mean Difference (I-J) } & \multirow[b]{2}{*}{ Std. Error } & \multirow[b]{2}{*}{ Sig. } & \multicolumn{2}{|c|}{$95 \%$ Confidence Interval } \\
\hline & & & & & Lower Bound & Upper Bound \\
\hline \multirow[t]{2}{*}{ PRODUCT } & PROCESS & -1.85000 & .74186 & .052 & -3.7147 & .0147 \\
\hline & POST-PROCESS & $-2.25000^{*}$ & .74186 & .014 & -4.1147 & -.3853 \\
\hline \multirow[t]{2}{*}{ PROCESS } & PRODUCT & 1.85000 & .74186 & .052 & -.0147 & 3.7147 \\
\hline & POST-PROCESS & -.40000 & .74186 & .865 & -2.2647 & 1.4647 \\
\hline \multirow[t]{2}{*}{ POST-PROCESS } & PRODUCT & $2.25000^{*}$ & 74186 & .014 & 3853 & 4.1147 \\
\hline & PROCESS & .40000 & .74186 & .865 & -1.4647 & 2.2647 \\
\hline
\end{tabular}

*. The mean difference is significant at the 0.05 level. 
The result of Scheffe test indicates that there is significant difference only between product and post process approaches in following test administration.

\section{DISCUSSION}

As stated earlier, 60 EFL students were non-randomly selected out of 100 EFL students. The researcher controlled and matched all the 60 students based on two controlled variables of sex, age, and students previous scores in last writing course. The students were divided into three groups and were nearly the same from viewpoint of sex but their previous sores in previous writing term were different. The result of statistics confirmed Hypothesis 1 and showed that there are significant differences among Iranian EFL learners' writing ability in terms of product, process, and post process writing approaches.

The researcher selected nearly equal number of female and male in all three groups and she measured all students' previous scores in previous writing term. Since there were not any significant differences among three groups in terms of their previous scores in previous writing term, it is concluded that post experimental differences are attributed to the conditions of the experiment, different types of writing approaches in this study, rather than to preexisting subject differences, such as sex and previous writing score in previous term.

The findings of the research rejects Kamimura's (2000) idea that L2 writing instruction should maintain a balance between process and product orientations to meet the needs of various L2 writers who come from non-English discourse communities. The researcher in this study proved priority of process approach over product approach.

The findings of the present study confirm Lee (2006). He emphasized process writing in his classes. Results of his study showed that students produced their final drafts in a more coherent manner with complex sentences, as indicated by increased analytic as well as holistic scores, T-units, and a global level of revision.

The findings of the study rejects He (2005) suggestions for using post process approach in writing classes. He (2005) strongly proposed a shift of the pedagogical focus in EFL writing instruction used in China. Instead of combined sentences in prescribed formula, students need a 'live' language, a powerful instrument to weave streams of thought. The present study did not show any priorities of post process approach over process approach.

\section{CONCLUSION}

The result of this study uncovered the following:

1. There are significant differences among Iranian EFL learners' writing ability in terms of product, process, and post process writing approaches.

2. There are significant differences among Iranian EFL learners' writing ability in terms of product and process writing approaches.

3. There are significant differences among Iranian EFL learners' writing ability in terms of product and post process writing approaches.

4. There are not significant differences among Iranian EFL learners' writing ability in terms of process and post process writing approaches.

5. Since there were not any significant differences among three groups in terms of their previous scores in previous writing term, we conclude that post experimental differences are attributed to the conditions of the experiment, different types of writing approaches in this study, rather than to preexisting subject differences, such as sex and previous writing score in previous term.

6. Post process approach did not show any significant priorities over process approach, but they both indicated remarkable priority over product approach.

\section{REFERENCES}

[1] Arnaudet, M.L. \&Barret, M.E. (1981). Paragraph development. A guide for students of English as a second language. New Jersey: Prentice Hall, Inc.

[2] Ashwell, T. (2000). Patterns of teacher response to student writing in a multiple-draft composition classroom: Is content feedback followed by form feedback the best method? Journal of Second Language Writing, 9 (3), 227-257.

[3] Atkinson, D. (2003). L2 writing in the post process era: Introduction. Journal of Second Language Writing, 12(1), 3-15.

[4] Badger, R. \& White, G. (2000). A process genre approach to teaching writing. ELT Journal, 54/2, 153- 160.

[5] Dempsey, M.S. PytlikZillig, L.M. Bruning, R.H. (2009). Helping pre-service teachers learn to assess writing: Practice and feedback in a web-based environment. AssessingWriting, 14, 38- 61.

[6] Ferries, D. \& Hedgcock, J. S. (2005). Teaching ESL composition: Purpose, process, and Practice (2nded.). London: LEA Publishers.

[7] Foo, T.CH.V. (2007). The effects of the process-genre approach to writing instruction on the expository essays of ESL students in a Malaysian secondary school. Unpublished doctoral dissertation. Kuala Lunpur, Malaysia.

[8] Jacobs, G. M. 2006). Issues in implementing cooperative learning. In S. G. McCafferty, G. M. Jacobs, \& A.CH. DaSilvaIddings (Eds.), Cooperative learning and second language teaching (pp. 30-49). Cambridge: Cambridge University Press.

[9] Harmer, J. (2004). How to teach writing. London: Longman 
[10] He, J. (2005). Applying post-process theory in university EFL writing classes in China. Working Papers in Composition \& TESOL, 1, 25-40.

[11] Kamimura, T. (2000).Integration of process and product orientations in EFL writing instruction. RELC Journal, 31(2), 1-29.

[12] Lee, Y. J. (2006). The process-oriented ESL writing assessment: Promises and challenges. Journal of Second Language Writing, 15, 307-330.

[13] Matsuda, P. K. (2003). Process and post-process: A discursive history. Journal of Second Language Writing, 12(1), 65-83.

[14] Nunan, D. (2001). Second language teaching \& learning. Boston: Heinle and Heinle Publishers.

[15] Raimes, A. (1985). What unskilled ESL students do as they write: A classroom study of composing. TESOL Quarterly, 19(2), 22, 9-258.

[16] Schmitt, N. (2002) (Ed.). An introduction to applied linguistics. London: Edward Arnold.

[17] Song, B. \& August, B. (2002). Using portfolio to assess the writing of ESL students: A powerful alternative? Journal of Second Language Writing, 11(1), 49-72.

[18] Swales, J. (1990).Genre analysis: English in academic and research settings. Cambridge: Cambridge University Press.

[19] Tribble, C. (1996). Writing. Oxford. Oxford University Press.

[20] Weigle, S. C. (2002). Assessing Writing. Cambridge: Cambridge University Press.

[21] Wilhelm, K. H. (2006). Teaching, practicing, and celebrating a cooperative learning model. In S. G. McCafferty, G. M. Jacobs, \& A. CH. DaSilvaIddings (Eds.), Cooperative learning and second language teaching(pp. 153-177). Cambridge: Cambridge University Press.

[22] Zamel, V. (1982). Writing: The process of discovering meaning. TESOL Quarterly, 16 (2),195-209.

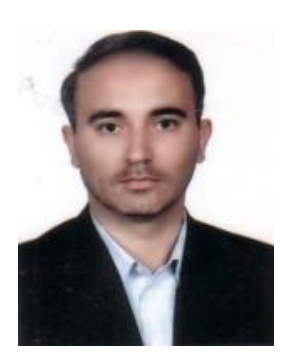

Hossein Hashemnezhad received his Ph.D. in TEFL from Islamic Azad University, Science and Research Branch, Tehran, Iran. He teaches at the Islamic Azad University, Khoy Branch. He also was the Dean of the College of Humanities in the Islamic Azad University, Khoy Branch. His research interests are language teaching as well as assessment. He has published and presented papers in national and international conferences and journals.

Nasrin Hashemnezhad is an MA student at the Islamic Azad University, Tabriz, Iran. She teaches English in SAMA, Islamic Azad University, Khoy Branch. Her interests are language teaching and methodology. 